\title{
Manpower allocation in a cellular manufacturing system considering the impact of learning, training and combination of learning and training in operator skills
}

\author{
Masoud Rabbani ${ }^{\mathrm{a}^{*}}$, Elahe Akbari ${ }^{\mathrm{b}}$ and Mahdi Dolatkhah ${ }^{\mathrm{c}}$
}

${ }^{a}$ School of Industrial Engineering, Collage of Engineering, University of Tehran, Tehran, Iran ${ }^{b}$ School of Industrial Engineering, Collage of Engineering, University of Tehran, Tehran, Iran ${ }^{c}$ School of Industrial Engineering, Collage of Engineering, University of Tehran, Tehran, Iran

\section{H R O N I C L E}

Article history:

Received: October 1, 2016

Received in revised format: No-

vember 16, 2016

Accepted: November 16, 2016

Available online:

November 20, 2016

Keywords:

Manpower allocation

Cellular manufacturing system

Operator's learning and training

Discrete event simulation

\begin{abstract}
A B S T R A C T
In this article, a manpower allocation and cell loading problem is studied, where demand is stochastic. The inter-cell and intra-cell movements are considered and attention is focused on assigning operators with different skill levels to operations, because cell performance in addition to load cell is dependent on manpower. The purpose of this article is manpower allocation in cellular manufacturing with consideration to learning and training policies. The manpower skill levels are determined in order to enhance production rate. The main contribution of this approach is the scenarios of training and learning in addition to the combination of training and learning being simulated. By using these three scenarios, the skill level of workers increase which reduces the processing time. In this regard cell layout is static where processing times and customer demand follow a normal distribution. As one of the significant costs of industrial unit is related to production cost, this study has attempted to reduce these costs by increasing the skill level of operator which causes to reduce the processing time. Scenarios are evaluated by using a simulation method that finally attained results indicate this simulation provides better manpower assignments.
\end{abstract}

\section{Introduction}

Cellular manufacturing $(\mathrm{CM})$ is a new method for establishing industrial units and it has attracted some attention during the recent decades. CM developed as an impressive response to the increasing product diversity as a result of rapidly changing customer desire and global competition (Egilmez et al., 2014). Cellular manufacturing derived from group technology (GT). GT is focused on the principle of grouping parts into families based on similarities in design or manufacturing (Balakrishnan \& Cheng, 2007). In cellular manufacturing systems products are classified based on physical similarity or process similarity to smaller units called cells. Lower work-in-process inventory, lead times, waiting times and queue sizes for a diversity of products with low to medium volume of yearly demand has been perceived as the most effective layout in cellular manufacturing (Wemmerlov \& Johnson, 1997). CMS has some cons. Machine utilization may be lower because of dedication (Balakrishnan \& Cheng, 2007). The need

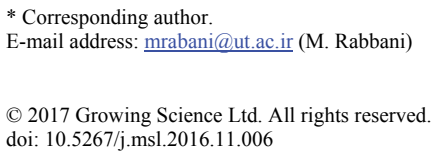


to focus on both technical issues and human issues is significant for the effective implementation of cellular manufacturing (Norman et al., 2002); because ignoring human issues can decrease cell manufacturing advantages noticeably (Bidanda et al., 2005). Manufacturing cells are separated into machineintensive cells and labor-intensive cells. Operator participation is restricted in machine-intensive cells as most of the processing is completed by automated machines. The operator's role is limited to loading and unloading the machines. In labor-intensive cells, operators play a main role in the performance of the cell and affects the output of the cell (Süer \& Tummaluri, 2008). Skill levels of the workers progress through learning or training. Operator skill level increases when he works on a single operation uninterruptedly for a definite amount of time. The progress or decline in skill levels rely on the operators' current skill levels (Tompkins et al., 1996; Süer \& Tummaluri, 2008). In addition to the allocation of operators, inter-cell movement and intra-cell movement are considered in this research. Inter-cell movement refers to the transfer of operators between cells, whereas intra-cell movement relates to operator transfers between machines within a cell (Cesani \& Steudel, 2005). In this study, the cell formation problem has been considered under static conditions and a fixed layout in which the problem data of cells is constant for a single time period. The majority of studies examine the deterministic cell manufacturing system design, where the manpower allocation problem is addressed, and operation times and customer demand are uncertain. Finally, to increase operator performance three scenarios of: training (training courses increase the skill level of the workers and this in turn requires a certain cost and time), learning (the skill level of workers gradually increases with the passing of time), and hybrid (combination of training and learning) are examined. Consequently, the problem can be summarized:

1) Determine the optimal cell layout

2) Assign products to cells (cell loading)

3) Determine operator assignments to operations for each product

Simulation of the three scenarios of training, learning and hybrid (combination of training and learning)

\section{Literature review}

Due to changes in demand for low cost, manufacturing systems must now respond at a quicker pace. Cell manufacturing is one of the solutions used in manufacturing enterprises to attain high productivity in an unsteady environment (Car \& Mikac, 2006). Reduction work in processing inventories costs, setup times and improvement of manpower relations and operator skill are proses of cellular manufacturing (Reene \& Sadowski, 1984). In the literature, cell loading has been considered extensively. Greene and Sadowski (1983) examined the variables influencing cellular manufacturing system where cell loading compromised the cell control function. Cell formation (CF) can conduct cell layout, and is the earliest problem of facility layout (Al- Mubarak et al. 2003). Chang, et al. (2009), Ahi, et al. (2009) and Mahdavia et al. (2008) considered the formation of family and equipment units, and offered integrated arithmetic of cell formation and cellular layout concurrently under various objectives. One of the fundamental focuses in $\mathrm{CM}$ is the consideration of human issues since disregarding this factor can extensively decrease profits of the cellular manufacturing (Mahdavi et al., 2010). Norman et al. (2002) proposed a mixed-integer programming model for allocating laborers to manufacturing cells with a specific aim to increase the benefit. Bidanda et al. (2005) presented assessment of the different scope of human issues included in CM. The model permits various diverse staffing choices (i.e., hiring and firing) due to minimize workforce-related and production costs (Wirojanagud et al., 2007). An avaricious heuristic approach methodology focused around individual learning rate for the enhancement of productivity in through focused on labor allocation was described by Nembhard, (2001). Wirojanagud et al. (2007) presented a workforce arranging model that includes individual laborer differences in ability to learn new skills and perform assignments. Different analysts have analyzed the effect and profit of training. Askin and Huang (1997) propose integer programming for allocating laborers in cells due to define a training program for workers. Hedge et al. (1994) recommend that the selection and training 
processes be connected within an organization and affirm that growing the skill levels of workers by training them creates the same impact as increasing the total skill levels of the work force through hiring. Training is performed to raise and/or maintain the essential skill in these laborers and as a result, enhance the possibility of job success and greater productivity. Huq, (1992) showed that the sort and scope of training required regularly relies on the nature of the production process, the size of the plant, and the prior methods of production. In the studies discussed, CMS layout and labor allocation are addressed but the impact on training and learning approaches to production costs, including inter-cell cost and intra-cell cost are not explained.

Table 1

Comparison of features of research conducted

\begin{tabular}{|c|c|c|c|c|c|c|c|c|c|c|c|}
\hline & 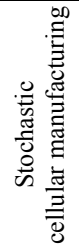 & 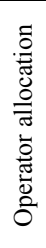 & 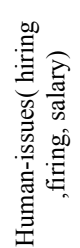 & 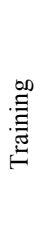 & 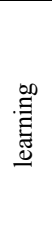 & 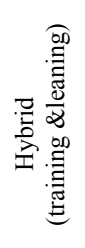 & 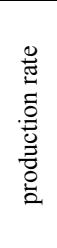 & 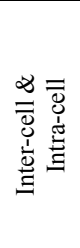 & 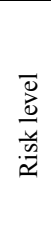 & 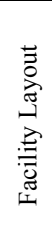 & 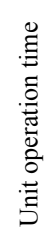 \\
\hline Egilmez et al., 2014 & $\sqrt{ }$ & $\sqrt{ }$ & $\sqrt{ }$ & & & & $\sqrt{ }$ & & & & \\
\hline Saeidi et al., 2014 & & & & $\sqrt{ }$ & & & $\sqrt{ }$ & & & & \\
\hline Egilmez et al., 2012 & $\sqrt{ }$ & $\sqrt{ }$ & & & & & & $\sqrt{ }$ & & & \\
\hline Mahdavi et al., 2010 & $\sqrt{ }$ & $\sqrt{ }$ & & & & & & & & & \\
\hline Aryanezhad et al., 2009 & & $\sqrt{ }$ & $\sqrt{ }$ & $\sqrt{ }$ & & & & & & & \\
\hline Süer \& Tummaluri, 2008 & & & & & $\sqrt{ }$ & & & & $\sqrt{ }$ & & \\
\hline Wirojanagud et al., 2007 & & $\sqrt{ }$ & $\sqrt{ }$ & & $\sqrt{ }$ & & & & & & \\
\hline Defersha \& Chen, 2006 & & & & $\sqrt{ }$ & & & $\sqrt{ }$ & & & & \\
\hline This study & $\sqrt{ }$ & $\sqrt{ }$ & & $\sqrt{ }$ & $\sqrt{ }$ & $\sqrt{ }$ & $\sqrt{ }$ & $\sqrt{ }$ & & $\sqrt{ }$ & $\sqrt{ }$ \\
\hline
\end{tabular}

\section{Problem description}

This study works with labor-intensive manufacturing cells. The machines and equipment are small and inexpensive in labor-intensive manufacturing cells. Operation time and customer demand are assumed to follow a normal distribution (Egilmez et al., 2014) because most real-world data are normally distributed by nature or have the ability to transform into a normal distribution and the majority of functions can be converted to a normal distribution (Javadi et al., 2013). Firstly, an implementation of cell manufacturing is explained. Then, the optimal layout is determined by considering the cycle time. The initial skill levels of operators are determined and according to the needs of each operation, the operator is assigned. Time and cost of courses in the training policy is elected and the policy is then implemented and the total cost of cellular manufacturing system, which includes the cost of production, inter-cell a cost , intra-cell cost and training cost, is evaluated. The skill level of each operator who participates in the training course increases and this in turn leads to a gradual reduction in the processing. Similarly, the steps mentioned in the training policy will be implemented in the learning policy. Finally, the hybrid scenario (combination of training and learning) is simulated and the costs of the three scenarios are compared with each other in order to choose the most effective scenario.

\subsection{Design of cellular manufacturing system: a case study}

In this project, the case study is a medium scale labor-intensive lamp manufacturing industry. The plant consists of 13 machines, and each machine performs a special type of operation (Chan \& Abhary, 1996). To increase the scale of the problem defined in order to better see the impact of three scenarios described, the number of products in the industry has shifted from one product to two products and the processing time has been changed from a uniform distribution to a normal distribution. Full plant capacity is designed for producing two lamps with 19 loading and unloading workers. Machine (M1) performs two different operations with one type of raw material, and produces the shells. Machines 
(M2_1), (M2_1) perform cutting operation and produces two different tubes (10 $\mathrm{mm}$ and $3 \mathrm{~mm}$ diameter) and the exhaust. The remainder of the machines performs simple assembly operations, so the service module is used for all the machines. Operation and products flow is shown in Fig. 1.

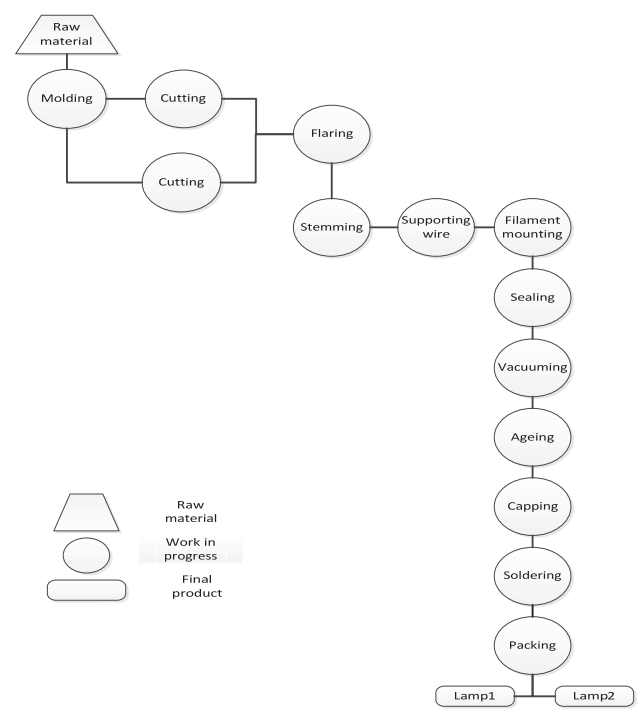

Fig. 1. Operation and products flow chart

\subsection{Optimal cellular manufacturing system}

In this study processing time follows a normal distribution. Processing time for each operation is defined by its own mean and standard deviation. The standard deviations of processing time are assumed as the $10 \%$ of the means (Egilmez et al., 2012) because detailed information from the standard deviation is not available. The production data necessary for the system, that is as shown in Table 2, is the number of workers to perform various tasks and operation data.

Table 2

Production data

\begin{tabular}{cccc}
\hline \multirow{2}{*}{$\begin{array}{c}\text { Machines } \\
\text { (operations) }\end{array}$} & Number of workers & Mean & Standard Deviation \\
\cline { 3 - 4 } & & 0.58 & 0.058 \\
\hline Moulding (M1) & 1 & 0.15 & 0.015 \\
\hline Cutting(M2_1) & 1 & 0.15 & 0.015 \\
Cutting (M2_2) & 1 & 0.48 & 0.048 \\
Flaring (M3) & 1 & 0.46 & 0.046 \\
Stemming (M4) & 4 & 0.44 & 0.044 \\
Supporting wire mounting (M5) & 1 & 0.50 & 0.050 \\
Filament mounting (M6) & 1 & 0.54 & 0.054 \\
Sealing (M7) & 3 & 0.42 & 0.042 \\
Vacuuming (M8) & 1 & 0.60 & 0.060 \\
Ageing (M9) & 1 & 0.59 & 0.059 \\
Capping (M10) & 1 & 0.47 & 0.047 \\
Soldering (M11) & 2 & 1.60 & 0.16 \\
\hline
\end{tabular}

If the cycle time and the number of cells is not clear, in this case it is assumed that the cycle time is equal to the maximum time of and design (Tomkins et al., 1996). This approach is used for determining the optimal number of cells. Due to the uncertain nature of the processing time and following a normal distribution, $\mu+3 \sigma$ are calculated for each operation. The cycle time is equal to the maximum $\mu+3 \sigma$ and the optimal number of cells in this cellular manufacturing system will be determined based on the cycle time. These calculations are shown in Table 3. 
Table 3

The result of cycle time calculations

\begin{tabular}{clll}
\hline Machines & $\mu+3 \sigma$ & Machines & $\mu+3 \sigma$ \\
\hline 1 & 0.754 & 7 & 0.702 \\
$2-1$ & 0.195 & 8 & 0.564 \\
\hline $2-2$ & 0.195 & 9 & 0.78 \\
3 & 0.624 & 10 & 0.767 \\
4 & 0.598 & 11 & 0.611 \\
5 & 0.572 & 12 & 2.08 \\
\hline 6 & 0.65 & & \\
\hline
\end{tabular}

After determining the optimal number of cells, according to the diagram production, the machines are allocated to the corresponding cell. The results of the allocation of the machines are given in table 4 and optimal layout diagram in Fig. 2 is shown.

\section{Table 4}

Optimal CMF

\begin{tabular}{cc}
\hline cells & Machines \\
\hline 1 & M1,M2-1,M2-2,M3 \\
2 & M4,M5,M6 \\
3 & M7,M8,M9 \\
4 & M10,M11 \\
5 & M12 \\
\hline
\end{tabular}

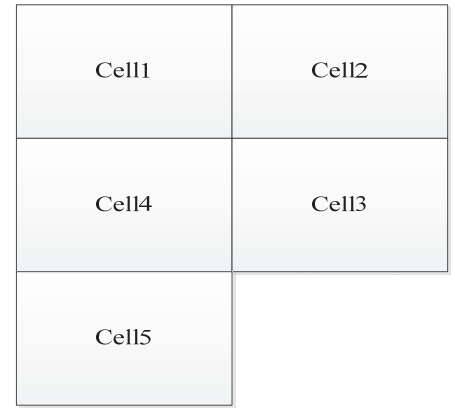

Fig. 2. Optimal layout diagram

The system produces two lamps, and each of them has its own demand. Due to the different needs of customers, the demand for these lamps is stochastic and follows a normal distribution. The demand data necessary for the system is shown in Tables 5 .

\section{Table 5}

Demand data

\begin{tabular}{ccc}
\hline \multirow{2}{*}{ Productions } & \multicolumn{2}{c}{ Demand } \\
\cline { 2 - 3 } & Mean & Standard Deviation \\
\hline Lamp 1 (10mm tube) & 87500 & 1000 \\
Lamp 2 (3mm tube) & 86500 & 900 \\
\hline
\end{tabular}

In this study, four skill levels are planned for operators. For instance the skill level of the operator can increase from skill level one to skill level two through two policies learning and training and enhance the performance of their cells. Inter-cell and intra-cell movements are considered in this article. The distances between and within cells are calculated by using Euclidean distance. The cost of transporting 
per unit is determined. To calculate the intra-cell cost and inter-cell cost, these distances must be multiplied by the cost of inter-cell flow and intra-cell flow. (The necessary information for calculating inter-cell cost and intra cell cost is shown in appendix A). In this study three scenarios have been investigated: First learning, second training, and third a combination of the two methods of training and learning. Necessary data for the three policies are shown in the Tables 6 and Table 7.

Table 6

Necessary Data for training courses

\begin{tabular}{ccc} 
skill levels & Cost of training course $(\$)$ & Time of training course(day) \\
\hline $1-2$ & 10000 & 10 \\
$2-3$ & 14000 & 15 \\
$3-4$ & 20000 & 20 \\
\hline
\end{tabular}

Table 7

Necessary Data for learning

\begin{tabular}{cc}
\hline skill levels & Time of learning \\
\hline $1-2$ & 30 \\
$2-3$ & 20 \\
$3-4$ & 15 \\
\hline
\end{tabular}

\subsection{Assumptions}

Family arrangements of parts can be based on design-orientation (Safaei et al., 2008) or can be based on production-orientation (Balakrishnan \& Cheng, 2007). Layout cells are divided into the two categories of discrete and continuous. In discrete mode, cells are arranged in blocks that have the same area and size that are pre-specified and in continuous mode, the dimensions of the cells depends on the size and type of machines in each cell (Javadi et al. 2013).

- In this project family arrangement of parts is based on production-orientation and the layout cells are considered to be discrete.

- Routing flexibility, which means that each operation can be done on one or more machine type with different times (Rafiei \& Koushan, 2012), is not allowed because it makes the complexity of the simulation.

Manufacturing cells can be defined as either machine-intensive or labor-intensive. In machine-intensive cells, the operator involvement is limited and the operation is mostly influenced by the machine performance. In labor- intensive manufacturing cells, operations are mainly carried out by the operators and the processing time of an operation can vary significantly from one unit of the job to the next unit depending on the operator and even for the same operator (Eglimez et al., 2012).The labor and skill level of workers have an effect on labor-intensive cells, which in turn affects the production rate (Eglimez et al., 2014).

- The main focus of this project is the issue of the allocation of manpower and operators play a major role, while labor-intensive cells have been investigated.

- Each operator works 8 hours a day.

\section{Methodology and results}

The proposed methodology consists of simulation CFM and defining the three scenarios to improve cell performance. The simulation software that is used in this study is AnyLogic because it has many useful features. AnyLogic is the market leader in simulation and modeling technology due to its flexibility and distinctive multi-method modeling capabilities. From supply chain and logistics to manufacturing and market analysis, all business areas are utilizing AnyLogic simulation software for better decision making throughout the entire business lifecycle. Three major methodologies used to build 
dynamic business simulation models: System Dynamics (SD), Process-centric ("Discrete Event", DE) modeling, and Agent Based modeling (AB); and AnyLogic is able to simulate all of these methodologies. Another feature of this software is that it can be used directly in Java code.

The proposed simulation consists of three phases:

1-Cell formation and cell loading

2-Manpower allocation

3- Implementation of the three scenarios of training, learning and hybrid.

\subsection{Phase 1: Cell formation and cell loading}

With respect to the optimal number of cells and the sequence of operations, the scope of each cell is determined by the software. Then, each cell can be loaded according to the requirements. The following sections will describe cell loading in detail. In cell 1 according to operation and products flow chart diagram machine 1, machine 2_1, machine 2_2 and machine 3 exist. Since each machine performs a specific operation, the service module is used to illustrate the operation. The raw materials enter the cell and after passing out of machine 1, are separated by the type of tube. To illustrate the separation of raw materials the select output modules is used. After cutting operations, other operations are similar for two lamps. Queue and hold modules are used to control the rate of entry of each product and act as a warehouse.

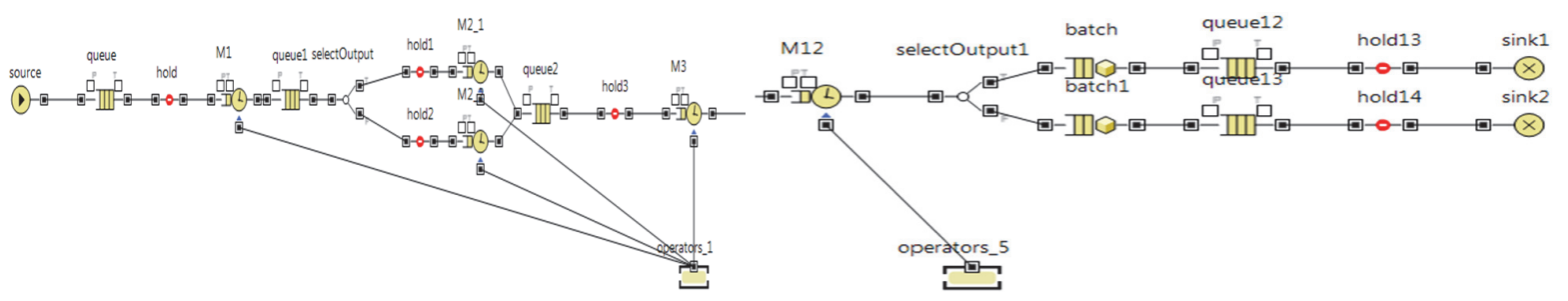

Fig. 3. Layout designed for cell 1

Fig. 4. Layout designed for cell 5

Due to the long processing time of operation 12, only machine 12 exists in cell 5 and this operation is the bottleneck. Then, depending on the type of lamp production and product labeling, lamps exit the system in batches of 100 .

\subsection{Phase 2: Manpower allocation}

Firstly, initial manpower skill levels for these five cells are determined. Then an operator is allocated according to the needs of each cell. The source module is used to indicate manpower allocation in batches of 100 lamps that exit from the system.

Table 8

Initial skill of operators

\begin{tabular}{llllll} 
Cells & 1 & 2 & 3 & 4 & 5 \\
\hline Skill level & 1 & 2 & 2 & 2 & 3 \\
\hline
\end{tabular}

\subsection{Phase 3: Implementation three scenarios training, learning and hybrid}

To enhance worker performance, the three scenarios of learning (the skill level of the worker gradually increases with the passing of time), training (training courses increase the skill level of the workers and this in turn requires certain cost and time) and hybrid (combination of training and learning) are examined. In learning mode, when an operator works on a single operation continuously for a certain amount 
of time, his skill level improves. Similarly, his skill level decreases when he doesn't perform an operation for a number of weeks (Süer \& Tummaluri, 2008). In the learning scenario, the mean of processing time gradually decreases. In other words, this decline can be attributed to a downward curve. To simulate the learning policy, the decision variable that determines the type of policy in addition to the parameters of time associated with learning must be defined. If the code is written in the AnyLogic software, the decision variable (policy) is equal to 1 , and the learning scenario will be occurring. The results of training scenario are shown in Table 9.

Table 9

The results of learning scenario

\begin{tabular}{lcc}
\hline & Policy=1 (learning) \\
\hline & Inter-cell cost & 1108984.75 \\
Average cost of 4 runs & Intra-cell cost & 2987228.25 \\
& Production cost & 3235617.262 \\
& Total cost & $7,341,830.26$ \\
\hline
\end{tabular}

In training mode, firstly the skill levels are defined and in order to increase the skill level to a higher level, a different cost and time are required (Norman et al. 2002). Training can reduce the mean of processing time at the end of the training course. For example, if the mean of processing time is 2 minutes, by increasing the skill level of the operator in the training course it will be reduced to 1.75 minutes, and this reduction occurs at the end of a training course. To simulate the training policy, the decision variable that determines the type of policy and the parameters of the cost and time associated with training courses need to be defined. If the code is written in the AnyLogic software, the decision variable (policy) is equal to 2 , and the training scenario will be occurring. The results of training scenario are shown in Table 10.

Table 10

The results of training scenario

\begin{tabular}{ccc}
\hline & Policy=2 (training) \\
\hline & Training cost & 166000 \\
Average of cost of 4 runs & Inter-cell cost & 1089490.75 \\
& Intra-cell cost & 2972045 \\
& Production cost & 3262743.02 \\
\hline
\end{tabular}

In hybrid mode, a combination of the two methods of training and learning is used in order to achieve better performance for the cell. In the hybrid policy, 5 binary decision variables (Cell1_hybrid_23, Cell1_hybrid_34, Cell2 hybrid_34, Cell3 hybrid_34 and Cell5_hybrid_34) exist. If the code is written in the AnyLogic software, the decision variable (policy) is equal to 3, and the hybrid scenario will be occurring. The decision in the hybrid scenario by the decision variables is as follows:

\begin{tabular}{|c|c|c|c|c|}
\hline & & & Skill level from & in- \\
\hline \multirow{2}{*}{ Cell1_hybrid_23 } & \multirow{2}{*}{ If Cell1_hybrid== } & 1 & 2 to 3 & train- \\
\hline & & 0 & 2 to 3 & learn- \\
\hline \multirow{2}{*}{ Cell1_hybrid_23 } & \multirow{2}{*}{ If Cell1_hybrid== } & 1 & 3 to 4 & train- \\
\hline & & 0 & 3 to 4 & learn- \\
\hline \multirow{2}{*}{ Cell1_hybrid_23 } & \multirow{2}{*}{ If Cell1_hybrid== } & 1 & 3 to 4 & train- \\
\hline & & 0 & 3 to 4 & learn- \\
\hline Cell1_hybrid_23 & \multirow{2}{*}{ If Cell1_hybrid== } & 1 & 3 to 4 & train- \\
\hline \multirow{2}{*}{ Cell1_hybrid_23 } & & 0 & 3 to 4 & learn- \\
\hline & If Cell1_hybrid== & $\begin{array}{l}1 \\
0\end{array}$ & $\begin{array}{l}3 \text { to } 4 \\
3 \text { to } 4\end{array}$ & $\begin{array}{l}\text { train- } \\
\text { learn- }\end{array}$ \\
\hline
\end{tabular}

Timetable for the implementation of the hybrid scenario is as follows: 
Table 11

Timetable of hybrid policy

\begin{tabular}{cccc}
\hline Policy=3 (hybrid) & Done in 30 minutes & Done in 50 minutest & Done in 65 minutes \\
\hline \multirow{2}{*}{ Increase skill level in Cell1 } & $1-2$ & $2-3$ & $3-4$ \\
& $2-3$ & $3-4$ & \\
\hline \multirow{2}{*}{ Increase skill level Cell2 } & $2-3$ & $3-4$ & \\
\hline \multirow{2}{*}{ Increase skill level Cell3 } & $3-4$ & $3-4$ \\
\hline \multirow{2}{*}{ Increase skill level Cell4 } & $2-3$ & \\
& $3-4$ & $3-4$ \\
\hline
\end{tabular}

In hybrid mode, there are 32 choices because 5 binary variable decisions with 2 modes exist and each choice runs four times due to the stochastic processing time. Five of the best results obtained after 128 runs are shown in Table 12.

Table 12

Result of hybrid scenario

\begin{tabular}{ccccccc}
\hline Cell5(3-4) & 0 & 0 & 0 & 1 & 1 \\
Cell3(3-4) & 0 & 0 & 0 & 0 & 1 \\
Cell2(3-4) & 1 & 1 & 0 & 0 & 1 \\
Cell1(3-4) & 1 & 0 & 1 & 0 & 1 \\
Cell1(2-3) & 0 & 0 & 1 & 1 & 1 \\
\hline rank & 1 & 2 & 3 & 4 & 5 \\
\hline Average of Total cost & 7324088.151 & 7324386.255 & 7329888.436 & 7333322.192 & 7342266.801 \\
\hline
\end{tabular}

By evaluating the results of the three scenarios, the hybrid scenario has a better performance and the reduced cost is greater. The results show that if skill level is increased from level 2 to level 3 by learning and from level 3 to 4 by training in cell 1 and from level 3 to 4 by training in cell 2 and from level 3 to 4 by learning in cell 5, the lowest cost will be produced. An important point is that operators in their initial skill level will need 90 day to satisfy customer demand. With the implementation of the three scenarios, the number of working days reduced from 90 days to 75 days to meet the demand. It is also observed with the use of the three scenarios, inter-cell cost and intra-cell cost have significantly reduced. The results of the simulation of CMS without any policies are shown in Table 13.

\section{Table 13}

Result of simulation of CMS without any policy

\begin{tabular}{ccc}
\hline & No Policy & \\
\cline { 2 - 3 } Average of cost of 4 runs & Inter-cell cost & 1255298.75 \\
& Intra-cell cost & 3160052.25 \\
& Production cost & 3848473.2 \\
& Total cost & $7,058,044.31$ \\
\hline
\end{tabular}

\section{Conclusion and future research}

In this research, manpower allocation in cellular manufacturing system has been investigated. In order to show the effects of the skill levels of the operator in the CMS performance, two approaches have been simulated. The first approach consists of two phases; cell formation and cellular layout problems 
are simulated simultaneously. Then, by considering operation and the product's flow chart, the cells are loaded. In the second approach, manpower allocation is simulated. The appropriate allocation of operators in terms of skill levels and needs of each operation have been presented. Then, the three scenarios of learning, training and hybrid are simulated in order to increase the skill level of the worker. The obtained results show that considering manpower allocation in CMS can affect both cell performance and cell costs. With the implementation of these three scenarios, the number of working days to meet the demand has increased. With enhancing the skill level of the operator, costs of inter-cell and intra-cell as well as the processing time are reduced. For example in this system, the lowest cost can be achieved when the skill level is increased from level 2 to level 3 by learning and from level 3 to 4 by training in cell 1 and from level 3 to 4 by training in cell 2 and from level 3 to 4 by learning in cell 5.Lastly, in future work, more experimentation with more skill levels, more operators and more operations can be simulated in order to see the effect in various scenarios better. To enhance the operators' skills, the implementation of encouraging policies (increasing salary) as well as punishment policies (decreasing salary) can increase the incentive for operators to provide better performance. In order to have better performance and reduced workdays, one can identify the bottleneck and allocate skilled workers who have finished his duties to that operation.

\section{References}

Ahi, A., Aryanezhad, M. B., Ashtiani, B., \& Makui, A. (2009). A novel approach to determine cell formation, intracellular machine layout and cell layout in the CMS problem based on TOPSIS method. Computers \& Operations Research, 36(5), 1478-1496.

Al-Mubarak, F., Khumawala, B. M., \& Canel, C. (2003). Focused cellular manufacturing: an alternative to cellular manufacturing. International Journal of Operations \& Production Management, 23(3), 277-299.

Aryanezhad, M. B., Deljoo, V., \& Mirzapour Al-e-Hashem, S. M. J. (2009). Dynamic cell formation and the worker assignment problem: a new model. The International Journal of Advanced Manufacturing Technology, 41(3-4), 329-342.

Askin, R., \& Huang, Y. (1997). Employee training and assignment for facility reconfiguration, Proceedings of the sixth IERC, Miami, FL, pp. 426-431.

Balakrishnan, J., \& Cheng, C. H. (2007). Multi-period planning and uncertainty issues in cellular manufacturing: A review and future directions. European Journal of Operational Research, 177(1), 281309.

Bidanda, B., Ariyawongrat, P., Needy, K. L., Norman, B. A., \& Tharmmaphornphilas, W. (2005). Human related issues in manufacturing cell design, implementation, and operation: a review and survey. Computers \& Industrial Engineering, 48(3), 507-523.

Car, Z., \& Mikac, T. (2006). Evolutionary approach for solving cell-formation problem in cell manufacturing. Advanced Engineering Informatics, 20(3), 227-232.

Cesaní, V. I., \& Steudel, H. J. (2005). A study of labor assignment flexibility in cellular manufacturing systems. Computers \& Industrial Engineering, 48(3), 571-591.

Chan, F. T., \& Abhary, K. (1996). Design and evaluation of automated cellular manufacturing systems with simulation modelling and AHP approach: a case study. Integrated Manufacturing Systems, 7(6), 39-52.

Chang, C.C., Wu, T.H., \& Chung, S.H. (2009). A novel approach for cell formation and cell layout design in cellular manufacturing system, in Management and Service Science, MASS'09. International Conference on. IEEE.

Egilmez, G., Erenay, B., \& Süer, G. A. (2014). Stochastic skill-based manpower allocation in a cellular manufacturing system. Journal of Manufacturing Systems, 33(4), 578-588.

Egilmez, G., Süer, G. A., \& Huang, J. (2012). Stochastic cellular manufacturing system design subject to maximum acceptable risk level. Computers \& Industrial Engineering, 63(4), 842-854.

Greene, T. J., \& Sadowski, R. P. (1983). Cellular manufacturing control. Journal of manufacturing systems, 2(2), 137-145. 
Greene, T. J., \& Sadowski, R. P. (1984). A review of cellular manufacturing assumptions, advantages and design techniques. Journal of Operations Management, 4(2), 85-97.

Hedge, J., Borman, W., \& Carter, G. (1994). Personnel selection and training. New York, John Wiley and Sons, Inc.

Huq, F. (1992). Labor issues in the implementation of group technology cellular manufacturing. Production and Inventory Management Journal, 33(4), 15.

Javadi, B., Jolai, F., Slomp, J., Rabbani, M., \& Tavakkoli-Moghaddam, R. (2013). An integrated approach for the cell formation and layout design in cellular manufacturing systems. International Journal of Production Research, 51(20), 6017-6044.

Mahdavi, I., Shirazi, B., \& Paydar, M. M. (2008). A flow matrix-based heuristic algorithm for cell formation and layout design in cellular manufacturing system. The International Journal of Advanced Manufacturing Technology, 39(9-10), 943-953.

Mahdavi, I., Aalaei, A., Paydar, M. M., \& Solimanpur, M. (2010). Designing a mathematical model for dynamic cellular manufacturing systems considering production planning and worker assignment. Computers \& Mathematics with Applications, 60(4), 1014-1025.

Nembhard, D. A. (2001). Heuristic approach for assigning workers to tasks based on individual learning rates. International Journal of Production Research, 39(9), 1955-1968.

Norman, B. A., Tharmmaphornphilas, W., Needy, K. L., Bidanda, B., \& Warner, R. C. (2002). Worker assignment in cellular manufacturing considering technical and human skills. International Journal of Production Research, 40(6), 1479-1492.

Safaei, N., Saidi-Mehrabad, M., \& Jabal-Ameli, M. S. (2008). A hybrid simulated annealing for solving an extended model of dynamic cellular manufacturing system. European Journal of Operational Research, 185(2), 563-592.

Süer, G. A., \& Tummaluri, R. R. (2008). Multi-period operator assignment considering skills, learning and forgetting in labour-intensive cells. International Journal of Production Research, 46(2), 469493.

Tompkins, J. A. White, J. A., Bozer, Y. A. and Tanchoco, M. A. (1996). Facility planning. John Wiley and Sons, Inc, New York.

Wemmerlov, U., \& Johnson, D. J. (1997). Cellular manufacturing at 46 user plants: implementation experiences and performance improvements. International journal of production research, 35(1), 29-49.

Wirojanagud, P., Gel, E. S., Fowler, J. W., \& Cardy, R. (2007). Modelling inherent worker differences for workforce planning. International journal of production research, 45(3), 525-553.

Appendix A: Inter-cell cost and Intra-cell cost

Necessary information to calculate the intra-cell costs is shown from Table A.1 to Table A.4

Table A.1.

The distance between machines in cell 1 (meter)

\begin{tabular}{ccccc}
\hline Cell1 & M1 & M2_1 & M2_2 & M3 \\
\hline M1 & 0 & 2 & 2 & 5 \\
M2_1 & 2 & 0 & 1 & 3 \\
M2_2 & 2 & 1 & 0 & 3 \\
M3 & 5 & 3 & 3 & 0 \\
\hline
\end{tabular}

Table A.2.

The distance between machines in cell 2(meter)

\begin{tabular}{cccc}
\hline Cell2 & M4 & M5 & M6 \\
\hline M4 & 0 & 2 & 4 \\
M5 & 2 & 0 & 2 \\
M6 & 4 & 2 & 0 \\
\hline
\end{tabular}


Table A.3.

The distance between machines in cell 3(meter)

\begin{tabular}{cccc}
\hline Cell3 & M7 & M8 & M9 \\
M7 & 0 & 3 & 4 \\
M8 & 3 & 0 & 1 \\
M9 & 4 & 1 & 0 \\
\hline
\end{tabular}

\section{Table A.4.}

The distance between machines in cell 4(meter)

\begin{tabular}{ccc}
\hline Cel14 & M10 & M11 \\
\hline M10 & 0 & 2 \\
M11 & 2 & 0 \\
\hline
\end{tabular}

Necessary Information to calculate the inter-cell costs is shown in Table A.5

Table A.5.

The distance between cells (meter)

\begin{tabular}{cccccc}
\hline & Cell1 & Cell2 & Cell3 & Cell4 & Cell5 \\
\hline Cell1 & 0 & 1 & 2 & 4 & 5 \\
Cell2 & 1 & 0 & 1 & 3 & 4 \\
Cell3 & 2 & 1 & 0 & 2 & 3 \\
Cell4 & 4 & 3 & 2 & 0 & 1 \\
Cell5 & 5 & 4 & 3 & 1 & 0 \\
\hline
\end{tabular}

The intra-cell flow cost and inter-cell flow cost are shown from Table A.6 to Table A.10

Table A.6.

Inter-cell flow cost

\begin{tabular}{cccccc}
\hline$\$$ & Cell1 & Cell2 & Cell3 & Cell4 & Cell5 \\
\hline Cell1 & 0 & 3 & 5 & 7 & 8 \\
Cell2 & 3 & 0 & 3 & 5 & 6 \\
Cell3 & 5 & 3 & 0 & 4 & 5 \\
Cell4 & 7 & 5 & 4 & 0 & 4 \\
Cell5 & 8 & 6 & 5 & 4 & 0 \\
\hline
\end{tabular}

Table A.7.

Intra-cell 1 flow cost

\begin{tabular}{ccccc}
\hline Cell1 & M1 & M2_1 & M2_2 & M3 \\
\hline M1 & 0 & 2 & 2 & 3 \\
M2_1 & 2 & 0 & 1 & 2 \\
M2_2 & 2 & 1 & 0 & 2 \\
M3 & 3 & 2 & 2 & 0 \\
\hline
\end{tabular}

Table A.8.

Intra-cell 2 flow cost

\begin{tabular}{cccc}
\hline Cel12 & M4 & M5 & M6 \\
\hline M4 & 0 & 1 & 3 \\
M5 & 1 & 0 & 2 \\
M6 & 3 & 2 & 0 \\
\hline
\end{tabular}


Table A.9.

Intra-cell 3 flow cost

\begin{tabular}{cccc}
\hline Cell3 & M7 & M8 & M9 \\
\hline M7 & 0 & 2 & 3 \\
M8 & 2 & 0 & 1 \\
M9 & 3 & 1 & 0 \\
\hline
\end{tabular}

Table A.10.

Intra-cell 4 flow cost

\begin{tabular}{ccc}
\hline Cel14 & M10 & M11 \\
\hline M10 & 0 & 2 \\
M11 & 2 & 0 \\
\hline
\end{tabular}

Appendix B: Production cost

Necessary data for production cost is shown from Table B.1. to Table B.2

Table B.1.

Production cost for each lamp

\begin{tabular}{cc}
\hline machines & Cost of production $(\$)$ \\
\hline M1 & 3 \\
M2_1 & 4 \\
M2-1 & 4 \\
M3 & 5 \\
M4 & 6 \\
M5 & 3 \\
M6 & 4 \\
M7 & 6 \\
M8 & 5 \\
M9 & 4 \\
M10 & 3 \\
M1 & 3 \\
M12 & 2 \\
\hline
\end{tabular}

Table B.2.

Cost of production

\begin{tabular}{cc}
\hline machines & Cost of production $(\$)$ \\
\hline M1 & 3 \\
M2_-1 & 4 \\
M2_1 & 4 \\
M3 & 5 \\
M4 & 6 \\
M5 & 3 \\
M6 & 4 \\
M7 & 6 \\
M8 & 5 \\
M9 & 4 \\
M10 & 3 \\
M1 & 3 \\
M12 & 2 \\
\hline
\end{tabular}


Appendix C: Layout designed

In cell 2 according to operation and products flow chart diagram machine 4 , machine 5, and machine 6 are excited. In this cell stemming and supporting wire mounting and filament mounting are performed.

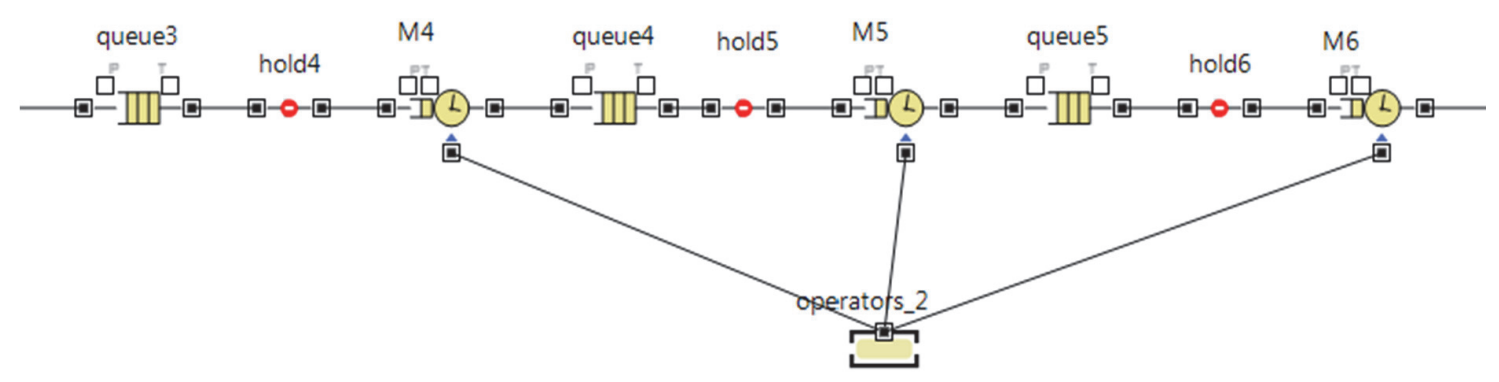

Fig. C.1. Layout designed for cell 2

On both lamps in cell 3 sealing, vacuuming and ageing operations are done. By putting the queue before the machine can be prevented from entering addition product after passing the specified volume of each lamp.

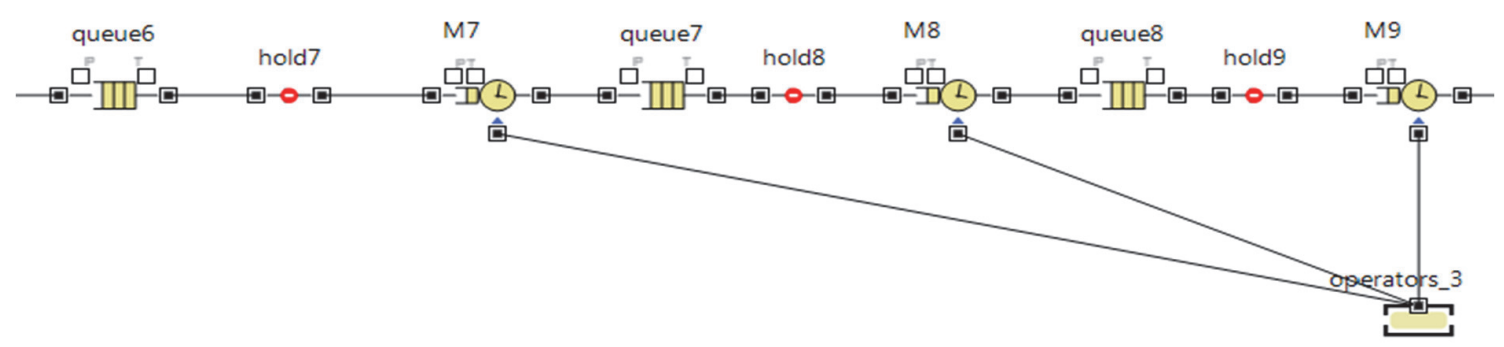

Fig. C.2. Layout designed for cell 3

In cell 4 according to operation and products flow chart diagram machine 10 and machine 11 are excited.

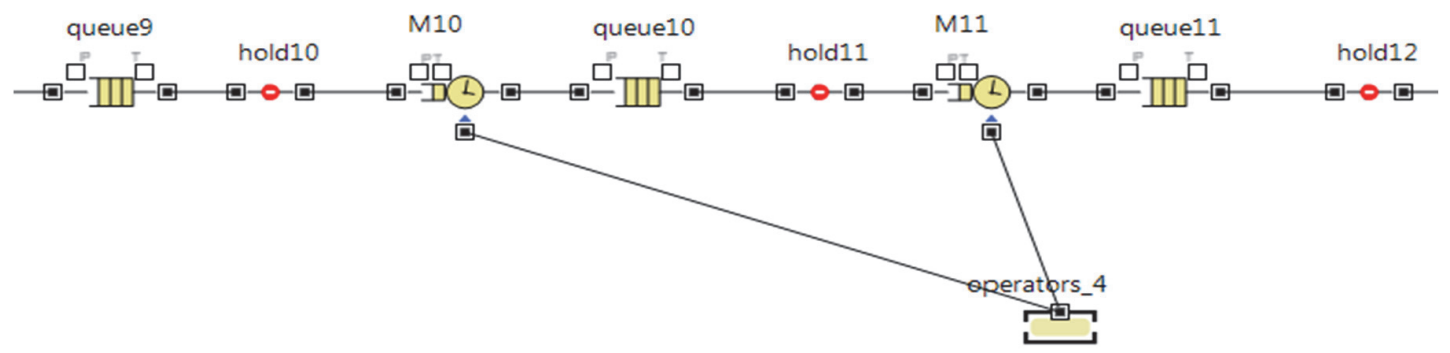

Fig. C.3. Layout designed for cell 4

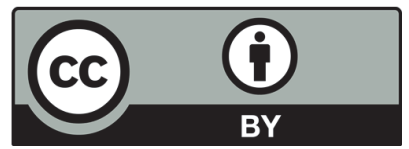

(C) 2017 by the authors; licensee Growing Science, Canada. This is an open access article distributed under the terms and conditions of the Creative Commons Attribution (CC-BY) license (http://creativecommons.org/licenses/by/4.0/). 